\title{
Reflection on the Connotation of Innovative Education in Colleges and Universities and Cultivation of Innovative Talents
}

\author{
Sun Cui \\ School of Economy and Management \\ Shenyang Aerospace University \\ Shenyang City, China
}

\begin{abstract}
Along with the continuous reform of our education, the understanding of innovative education is deepened. In the era of globalization, it is clear to attach importance to the innovative education and the cultivation of innovative talents in order to achieve the development of national economy. In 21 st century, ultimately, the competition of each country is the competition of talents. The innovative talents are of special significance for a nation, and innovative education in colleges and universities is very important to the cultivation of innovative talents. This paper introduced the connotation of innovative education in colleges and universities, pointed out the importance of innovative education for innovative talents cultivation, which constantly promotes the development of our educational cause, and put forward reasonable reform measures for the cultivation of innovative talents, which aimed to realize the strategy of revitalization of China through talents development.
\end{abstract}

Keywords-educational reform in colleges and universities; connotation of innovative education; innovative talents; talent cultivation; thinking and exploration

Innovation is the power of development, and the essential demand of science and technology. Without continuous innovation, the continuous would be impossible. Nowadays, with the rapid development of science and technology, the fierce international competition relies on the innovative talents strongly, and a batch of talents with courage to explore and being good at innovation will directly affect the overall strength of a country. Education is key to the cultivation of talents, so education is very important to a country. In terms of the present situation, innovative education is the inevitable trend of the development of education; the development of innovative education will affect the cultivation of innovative talents and then the increase of comprehensive national strength, so colleges and universities shoulder the sacred mission, which is the international fundamental.

\section{THE CONNOTATION ANALYSIS OF INNOVATIVE \\ EDUCATION IN COLLEGES AND UNIVERSITIES}

Innovative education is high-level education. In the current educational reform, the reform places an emphasis on the innovative education. Innovative education mainly focuses on the cultivation of innovative spirit and ability among college students so as to adapt to the rapid development of science and technology and make contributions to the society.

\section{A. Connotation of innovative spirit and innovative} ability

Innovative spirit. Innovative spirit, a kind of scientific spirit, is to bravely question the traditional views and theories, and put forward new views; the external expression is a kind of creative desire and pioneering spirit, and a kind of psychological orientation of actively exploring new things and awareness of pursuing innovation. Innovative education is to motivate the subjective consciousness of students and their thirst for knowledge, and guide the students to explore the unknown area. In the teaching process, teachers should cultivate students' thinking ability, constantly infuse question consciousness, encourage students to actively think about the problems in society and scientific research, be brave to raise their own opinions, flexibly apply the learned knowledge, and solve relevant problems so as to realize innovation.

Innovative ability. Innovative ability is the comprehensive realization of thinking ability, knowledge and skills in the process of participating in activities or problem discussion. Innovative ability is affected by intelligence factor and non-intelligence factors, such as faith, strategy, etc. It is the combination of abilities in every aspect, and the necessary part for scientific and technological society. Innovative education cultivates the innovative ability in many aspects, including the knowledge system and practical ability.

B. The relationship between innovative spirit and innovative ability

For people, the combination of innovative spirit and innovative ability is the creativity; a people with creativity can be the innovative talents. Innovative spirit is the soul and power for innovation, and it is the intrinsic requirement for innovative ability. Innovative spirit is necessary for emancipating our mind in order to realize innovation, constant development and progress. Innovative ability is the external manifestation of creativity; the people with innovative thinking and without innovative ability can also not adapt to the 
development of society, and only the combination of the two can fully embody the creativity.

\section{THE PROBLEMS IN THE CULTIVATION OF}

\section{INNOVATIVE TALENTS}

\section{A. The traditional teaching mode is not in accordance with the requirement of innovative education}

Due to the traditional educational concept, our education mainly cultivates the knowledge talents. The centering theories of knowledge have deep influence on the course development, and it emphasizes the priority of subject knowledge in the course development. However, the knowledge-centered theory has great restrictions on the innovative education. There are great differences between our traditional teaching mode and innovative education, which affects the promotion of innovative education and the cultivation of innovative talents. The course setting attaches great importance to the knowledge and the arrangement of subject isolates the original complete knowledge, which affects the application of knowledge. The traditional teaching system severely hinders the implementation of innovative education, which regards students as the objects of acquiring knowledge; students have been passively acquiring knowledge with least initiative; however, innovative education attaches great importance to the cultivation of subjective exploration competence, but traditional education system severely weakens the cultivation of innovative spirit, which goes against the further development of innovative education.

\section{B. The course arrangement neglects the importance of practical teaching}

On the course arrangement, colleges and universities pay attention to the cultivation of the students' theoretical knowledge rather than the practical ability. Although there are arrangements for experimental curriculum, the low execution and severe formalization restrict the development of innovative education. The current practical teaching is to verify the theoretical knowledge, which unilaterally strengthens the views among students that what taught by teachers is truth, highlights the authority of teachers and neglects the subjectivity of the students. It should be known that the practical courses are very important to the innovative education; the innovative spirit and innovative ability are all cultivated in the practice; the thinking ability will be constantly exercised and innovative ability gradually cultivated only by constant practice in the experiment, finding problems and raising questions by themselves. Too much attention to the inculcation of theoretical knowledge will obliterate the thinking ability of students through practice and thought and restrict the development of innovative consciousness. The knowledge-based talents are not in accordance with the current social needs.

\section{The defects in educational management mechanism}

Analyzed from management mechanism in our country, the traditional management mechanism is lack of humanistic care, but is more of a constraint, which also restricts the development of innovative education and the cultivation of innovative talents in colleges and universities. From microscopic perspective, it is mainly reflected in the management of students by schools; the strict management mode severely hampers the initiative of students, makes some students acquire some rebellious mental illness, rejects the student management and contradicts the school education. In student management, the relations between students and teachers are strained due to adhering to the principle of limited systems and be lack of corresponding humanistic care; in the long-term system restriction, the innovative consciousness of students is obliterated, which leads to the phenomenon of being lack of innovative thinking and abilities among students. From macro-perspective, government agencies have rigid management of colleges and universities, and the colleges and universities have to follow the arrangements of agencies to a great extent, which makes the teaching arrangement lose their own initiative, decision-making and teaching characteristics, and goes against the cultivation of innovative talents. The thinking of the talents cultivated in this rigid teaching management mode is rigid and without flexibility, however, the thinking of innovative talents is jumping, so this kind of mode will definitely restrict the development of innovative education. The uniformity of educational mechanism also dilutes the innovative consciousness of students, and greatly restricts the cultivation of innovative talents. In this era of knowledge-driven economy, the development of innovative education should be valued, and the importance of innovative talents is more and more prominent.

\section{THE STRATEGY OF CULTIVATING INNOVATIVE} TALENTS IN THE INNOVATIVE EDUCATION OF

\section{COLLEGES AND UNIVERSITIES}

\section{A. Achieve the change of educational thought and seize the essence of innovative education}

Innovative thinking and innovative ability are essential for talents in the 21st century, so colleges and universities should change the educational thought, seize the essence of innovative education and deepen the reform of innovative education. On the concept of talents cultivation, schools should transform from knowledge-based talents into innovative talents, not just only pay attention to the instruction of textbook knowledge and skills, but also let students realize the flexible use of knowledge and skills; cultivate the creative thinking of students through practical curriculum, pay more attention to the lifelong learning of students, build the creative academic atmosphere, cultivate their innovative consciousness and ability, and inspire their potentials. The innovative education and traditional education have essential differences. In the 
educational reforms, colleges and universities should change in nature rather than seemingly implement the innovative education; through a variety of creative reform measures, colleges and universities can constantly make progress in the reform of innovative education system.

\section{B. Optimize the course system and teaching content}

On the course arrangement, schools should pay attention to the proportion of practical courses in the arrangement, get rid of the current arrangement of too much theoretical courses, which makes the practical courses be formalized. In construction of reasonable course structure system, it should be pointed out that except solid knowledge base and reasonable knowledge structure, the active innovative thinking and strong practical ability are also necessary and important to the innovative talents. At present, the curriculum provision and teaching content in the colleges and universities are very rigid to the cultivation of students, so the cultivated students have poor comprehensive ability and social adaptability, which will be hard to meet the social demands.

On reform of course system and teaching content, the cultivation of student's innovation ability and various comprehensive abilities should be highlighted. With the purpose of cultivating students with comprehensive basic knowledge, proficient professional skills and outstanding innovative ability, the course arrangement will break the traditional science-humanities division, and focus on the overall promotion of students' knowledge and quality as well as the continuous update of teaching content. The requirement of learning content in innovative education is to keep up with the world; the teaching content pay attention to inspiring the exploration and creative thinking of students, which is the target of innovative education.

\section{To optimize teaching methods and achieve modernized teaching}

The reform of teaching methods is necessary; good teaching methods can stimulate the students' learning interest and innovative thinking. In the modernized education, the traditional teaching methods can't meet the actual needs; the modernized teaching media can better stimulate the creative thinking of students, and there is qualitative transition whether from the sense or the acquisition of knowledge; however, it is not desirable purely by relying on the multimedia, and teachers should pay attention to interacting with the students while taking advantage of the multimedia; in this way, the phenomenon that students can't keep up with the teachers and lose the confidence can be avoided, so the requirements for teachers should be improved because of the optimization of teaching methods.

\section{To perfect the system of teaching evaluation}

The existing student evaluation system has higher requirements of student achievement; students can't get rid of the clutch of exam-oriented education, and are caught in the mode of memorizing mechanically in order to cope with exam, which is in contrary with the innovative education. Therefore, it's crucial to perfect the system of exam and evaluation. Implement the diversification of test, change the traditional testing mode and diversify the evaluation system for students; the innovative work and other activity achievements can be added in the evaluation system, which will be good to stimulate the students' innovation enthusiasm and create the environment of innovation in the whole school.

\section{CONCLUSION}

Innovation education is one of the important targets for our education reform; it is more suitable for the standard of innovative talents cultivation, so each college or university should be clear about the current task; learn the advanced foreign mode whether from ideology, curriculum or the teaching method, and be clear about the unreasonable parts of our teaching model; the traditional teaching mode has last a long time, but the root of development is to advance with the times; the most important thing is to deepen the reform of teaching system and cultivate all-sided innovative talents for our country, which will place us in a good position in the face of international competition; in the era of science, technology and information, talents are of great importance to a country, especially the innovative talents, who are the main force of national development, so the cultivation of innovative talents is very important at present.

\section{REFERENCES}

[1] Fan Chunli. Reflection on the connotation of innovative education in colleges and universities and the cultivation of innovative talents $[\mathrm{J}]$. Journal of Jianghan University (social science edition), 2010,03:110-112.

[2] Lu Man. The new reflection on the cultivation of innovative talents in colleges and universities [J]. Journal of Heilongjiang college of education,2010,10:13-14.

[3] Jiang Wei, Zhang Qiuhui, Weng Jiamin. The strategy analysis on the cultivation of innovative talents under the background of quality-oriented education [J]. Human resource management, 2014,02:156-157.

[4] Zhang Xiying. Reflection on textbook construction in colleges and universities and the cultivation of innovative talents $[\mathrm{J}]$. A vast view on publishing, 2014,18:80-81.

[5] Li Xue. Reflection on the cultivation of innovative talents in the 21st century--interview record on Tian Jianguo, who is doctoral supervisor, professor, vice chairman of Association of Chinese Higher Education Management [J]. Economist, 2011,02:6-7.

[6] Cheng Peng, Peng Yan, Wang Huan. Thoughts triggered by the comparison of innovative talents cultivation mode in colleges and universities $[\mathrm{J}]$. Guide to technological innovation, 2011,09:142-143.

[7] Liu Wei. Reflection on the construction of personnel training system for innovation and entrepreneurship in colleges and universities [J]. Science of education, 2011,05:64-67.

[8] Chang Xiujuan. Reflection on the cultivation of innovative talents in colleges and universities $[\mathrm{J}]$. Heilongjiang education (higher education research and evaluation), 2012,03:80-81.

[9] Lv Lili. Reflection on implementation of scientific education in the cultivation of innovative talents in colleges and universities [J]. Journal of Changzhou College of information technology, 2012,02:11-13.

[10] Li Tao. Discussion on the cultivation of innovative talents and innovative practical education in colleges and universities [J]. Social scientist, 2012,S1:175-176.

[11] Zhang Zhijun, Xu Wenhui, Li Sainan. Discussion on the educational strategy of the cultivation of innovative talents in 
colleges and universities [J]. Journal of Baicheng Normal College, 2012,05:93-96.

[12] Tie Raorao. Discussion on the cultivation of innovative talents and humanistic quality education in colleges and universities [J]. Art education, 2014,11:50.

[13] Wu Yadong. Discussion on the cultivation of innovative talents and quality-oriented education in colleges and universities [J].
Science and technology in western China, 2013,05:116-117.

[14] Hu Jinzhi. Deep reflection on the cultivation of innovative talents and construction of teaching body in colleges and universities [J]. College education, 2013,16:16-17.

[15] Liu Liyuan. Reflection on the cultivation of innovative talents in colleges and universities [J]. Science and technology horizon, 2015,19:112-113. 